Assembly Language Programming for the BBC Microcomputer 


\section{Macmillan Microcomputer Books}

General Editor: Ian Birnbaum

(General Adviser (Microelectronics in Education)

Education Department, Humberside County Council))

Advanced Graphics with the Acorn Electron

Ian O. Angell and Brian J. Jones

Advanced Graphics with the BBC Model B Microcomputer

Ian O. Angell and Brian J. Jones

Interfacing the BBC Microcomputer

Brian Bannister and Michael Whitehead

Assembly Language Programming for the BBC Microcomputer (second edition)

Ian Birnbaum

Using Your Home Computer (Practical Projects for the Micro Owner)

Garth W. P. Davic

The Future of the Microcomputer in Schools

Nick Evans

Microchild: Learning through LOGO

Serafim Gascoigne

The Purple Planet-Micro-PROLOG for the Spectrum $48 \mathrm{~K}$

Serafim Gascoigne

Turtle Fun - LOGO for the Spectrum $48 \mathrm{~K}$

Serafim Gascoigne

A Science Teacher's Companion to the BBC Microcomputer

Philip Hawthorne

Operating the BBC Microcomputer: A Concise Guide

Graham Leah

Sorting Routines for Microcomputers

Keith McLuckie and Angus Barber

Using Sound and Speech on the BBC Microcomputer

Martin Phillips

Beginner's Guide to Interfacing the BBC Microcomputer Martin Phillips

The Complete Disc Manual for the BBC Microcomputer

R. I. M. Sadek

File Handling on the BBC Microcomputer

Brian J. Townsend

Good BASIC Programming on the BBC Microcomputer

Margaret White

\section{Other books of related interest}

Advanced Graphics with the IBM Personal Computer Ian O. Angell

Advanced Graphics with the Sinclair ZX Spectrum Ian O. Angell and Brian J. Jones

Micro-Maths Keith Devlin

Geometric and Artistic Graphics: Design Generation with Microcomputers Jean-Paul Delahaye

Practical BASIC Programming Peter Gosling

Word Processing with Amstrad: The PCW8256 and 8512 Ron Hughes

The Commodore 64 in Action M. M. Novak

Computer Literacy: A Beginners' Guide Vincent Walsh

The Computer Handbook: A Businessman's Guide Charles Jones

Understanding Management Software Andrew Leigh 


\title{
Assembly Language Programming for the BBC Microcomputer
}

\author{
Ian Birnbaum \\ General Adviser \\ (Microelectronics in Education) \\ Education Department, \\ Humberside County Council
}

Second Edition

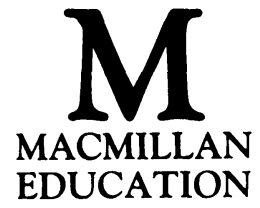


All rights reserved. No reproduction, copy or transmission of this publication may be made without written permission.

No paragraph of this publication may be reproduced, copied or transmitted save with written permission or in accordance with the provisions of the Copyright Act 1956 (as amended).

Any person who does any unauthorised act in relation to this publication may be liable to criminal prosecution and civil claims for damages.

First edition 1982

Reprinted 1982, 1983 (three times)

Second edition 1984

Reprinted 1985, 1986, 1987

Published by

Higher and Further Education Division

MACMILLAN PUBLISHERS LTD

Houndmills, Basingstoke, Hampshire RG21 2XS

and London

Companies and representatives

throughout the world

Typeset by Photo-Graphics, Honiton, Devon.

British Library Cataloguing in Publication Data

Birnbaum, Ian

Assembly language programming for the BBC

Microcomputer.-2nd ed.-(Macmillan microcomputer books)

1. BBC Microcomputer.-Programming

I. Title

001.64'2 QA76.8.B3

ISBN 978-0-333-37096-4

ISBN 978-1-349-07360-3 (eBook)

DOI 10.1007/978-1-349-07360-3

The accompanying cassette is

ISBN 978-0-333-38267-6

Dedicated to Theresa 


\section{Contents}

Preface to the First Edition ix

Preface to the Second Edition $\quad x i$

1 Preliminary Ideas 1

1.1 What is a computer? 1

1.2 How memory is organised in a computer 2

1.3 How the 6502 microprocessor is organised 5

1.4 Machine code and assembly language 8

1.5 Compilers and interpreters: Why use assembly language? 10 Exercise 1.1 11

2 Assignments $\quad 12$

$\begin{array}{ll}2.1 \text { The accumulator } & 12\end{array}$

2.2 What is the assembly language equivalent of

LET NUM1 = 17? 12

2.3 More on the immediate, absolute and zero page $\begin{array}{ll}\text { addressing modes } & 14\end{array}$

2.4 What is the assembler equivalent of LET NUM2 = NUM1? 15

Exercise 2.1 16

2.5 Where to put machine code programs in the BBC Micro 17

2.6 How to input assembly language programs into the $\begin{array}{ll}\text { BBC Micro } & 19\end{array}$

2.7 Storing numbers larger than 256 in assembly language 22

3 Addition and Subtraction 23

$\begin{array}{lll}3.1 & \text { The arithmetic unit } & 23\end{array}$

3.2 What is the assembly language equivalent of some simple BASIC statements involving addition? 24

3.3 The importance of carry 25

Exercise $3.1 \quad 26$

3.4 Adding numbers that are greater than 256: multiple
precision arithmetic

Exercise $3.2 \quad 28$

$\begin{array}{lll}3.5 & \text { Subtraction } & 28\end{array}$

3.6 The function of the carry flag in subtraction:

Exercise $3.3 \quad 31$ 
3.7 Positive and negative numbers: signed arithmetic 31 Exercise 3.4 34

$\begin{array}{lll}3.8 & \text { Logical operations } & 34\end{array}$

Exercise 3.5 36

3.9 A new addressing mode: implied addressing 36

4 Decision-making in Assembly Language $\quad 37$

$\begin{array}{lll}4.1 & \text { The processor status register } & 37\end{array}$

4.2 Decision-making using the microprocessor 38

4.3 The assembly language equivalents of some BASIC conditional statements: I: Use of the $\mathrm{N}$ and Z flags 39

Exercise 4.1

4.4 The assembly language equivalents of some BASIC conditional statements: II: Use of the CMP instruction 43 Exercise $4.2 \quad 46$

4.5 Comparing numbers greater than $255 \quad 47$

Exercise 4.3 49

4.6 Typing assembly language programs with labels into the BBC Micro 49

$\begin{array}{lll}4.7 & \text { Relative addressing } & 51\end{array}$

4.8 Using branching in the addition and subtraction of unsigned numbers: INC and DEC 54

Exercise $4.4 \quad 55$

4.9 Monitoring problems of sign using branching 55

$\begin{array}{ll}\text { Exercise 4.5 } & 57\end{array}$

5 Loop Structure in Assembly Language $\quad 59$

$\begin{array}{lll}5.1 & \text { Loop structures } & 59\end{array}$

5.2 Index registers: some new instructions 59

5.3 The assembly language equivalent of a FOR...NEXT loop 60 Exercise 5.1 63

5.4 FOR...NEXT loops of more than 256 cycles 63 Exercise 5.2 66

5.5 The equivalents of a REPEAT...UNTIL and a REPEAT
WHILE...ENDWHILE loop

5.6 Arithmetic and logical operations concerning the $\mathrm{X}$ and $\mathrm{Y}$ $\begin{array}{ll}\text { registers } & 67\end{array}$

$\begin{array}{ll}\text { Exercise 5.3 } & 70\end{array}$

5.7 Some example programs using loop structure $\quad 70$ $\begin{array}{ll}\text { Exercise 5.4 } & 73\end{array}$

6 Indexed Addressing $\quad \mathbf{7 4}$

$\begin{array}{ll}6.1 \text { Moving a section of memory } & 74\end{array}$

6.2 Improving the program $\quad 75$

$\begin{array}{ll}\text { Exercise 6.1 } & 76\end{array}$ 
6.3 The range of instructions for which indexed addressing is available

$\begin{array}{ll}6.4 \text { Arrays } & 78\end{array}$

Exercise 6.2 81

6.5 A fundamental data structure: the queue 82

Exercise 6.3 $\quad 87$

6.6 The assembler equivalent of PRINT $\quad 88$

Exercise 6.4 92

6.7 The assembler equivalent of GET\$, INKEY\$ and INPUT A\$ 92

Exercise 6.5 97

6.8 Macros, conditional assembly and tables: simplifying VDU statements 97

Exercise 6.6 101

7 Indirect Indexed Addressing 102

$\begin{array}{ll}7.1 \text { Moving a section of memory } & 102\end{array}$

7.2 A better method 105

Exercise 7.1 108

7.3 Inputting a series of strings of varying lengths 109

7.4 Sorting a series of fixed length records 111

Exercise 7.2 113

7.5 Sorting a series of 32-bit signed integers 114

Exercise 7.3 116

7.6 Sorting a series of variable length strings 116

Exercise $7.4 \quad 121$

7.7 Indirect jumps and jump tables 121

Exercise 7.5 123

8 Multiplication and Division $\quad 124$

8.1 A simple multiplying algorithm for decimal numbers 124

8.2 A corresponding algorithm for binary numbers 124

8.3 Programming a 4-bit microprocessor to perform the multiplication algorithm 125

8.4 A program to model the multiplication algorithm 128

8.5 A more efficient algorithm for multiplication 131

8.6 More efficiency still: accumulator addressing 132 Exercise 8.1 133

8.7 An interlude: outputting numbers using Binary Coded Decimal 133

Exercise $8.2 \quad 137$

8.8 A second interlude: a pseudo-random number generator 137

8.9 A third interlude: copying the high-resolution screen to a printer 
$\begin{array}{ll}8.10 \text { Division } & 145\end{array}$

Exercise 8.3 147

8.11 A second approach to division $\quad 148$

Exercise 8.4 150

9 The Stack: Subroutines and Interrupts 151

9.1 The concept of a stack 151

9.2 The stack and nested subroutines 153

9.3 Interrupts $\quad 156$

9.4 Passing parameters to and from subroutines 163

9.5 Three examples of using registers to pass parameters 167 Exercise 9.1 171

9.6 Two important subroutines $\quad 172$ $\begin{array}{ll}\text { Exercise 9.2 } & 179\end{array}$

9.7 Further uses of the stack 179

Exercise 9.3 182

$\begin{array}{lll}9.8 \text { Timing } & 182\end{array}$

Exercise 9.4 185

9.9 Screen scrolling: how it operates 185

$\begin{array}{ll}\text { Exercise } 9.5 & 188\end{array}$

10 Some Utility Programs $\quad 189$

$\begin{array}{llr}10.1 & \text { Introduction } & 189\end{array}$

10.2 Program 1: RETRIEVE 189

10.3 Program 2: INTSORT 192

10.4 Program 3: STRINGSORT 196

10.5 Program 4: REMSPACE 200

10.6 Program 5: MEMORYHUNT 205

10.7 Program 6: MC-MONITOR 209

Exercise 10.1 223

Appendix 1: 6502 Instruction Set 225

Appendix 2: Full Block Diagram of 6502 Architecture 246

Appendix 3: Indexed Indirect Addressing 247

Appendix 4: Floating-point Representation 251

Appendix 5: Flowchart Symbols and Conventions Used in This Book 254

Appendix 6: Further Uses of OPT 255

Appendix 7: The User Port 256

Appendix 8: $\quad$ Differences between BASIC 1 and BASIC 2

Answers to Exercises $\quad 269$

$\begin{array}{ll}\text { Index } & 318\end{array}$

Details of Cassette $\quad 322$ 


\section{Preface to the First Edition}

Every BBC Microcomputer, whether model A or model B, comes equipped with an immensely powerful and very fast assembler. What is more, assembly language statements and BASIC statements can be freely mixed, so hugely increasing the programmer's potential control over the machine.

This book shows you how to establish that control. It assumes that you are proficient in BASIC, for if you are not this is probably not the best time to learn assembly language. But it assumes no knowledge of assembler at all, taking you step by step from the basics to their complex implementation.

Since every user of the BBC Microcomputer assembler will have a working knowledge of BASIC, it is possible to use that knowledge to motivate and illustrate the ideas in assembly language. This book takes that approach, and this should help you to master assembly code, for you will always be acquainted with the fundamental concepts by seeing their connection with BASIC.

I had three types of readers in mind in writing this book. Firstly, all current owners of BBC Microcomputers who want to extend their knowledge into machine code. To help them with self-instruction, this book contains a considerable number of exercises and a full solution is provided for every one. Secondly, the teacher or student of computer science who wants to use this text in a structured course. The book is the result of many years of teaching experience, and it is designed according to a teaching strategy that the author has found to be very successful.

And thirdly, those people, already experienced BASIC programmers, who are wondering whether to buy the BBC Microcomputer, when there seems to be so much competition from cheaper and seemingly comparable computers. This book should help to convince them that the BBC Micro is worth the extra expense. Quite apart from its superb BASIC, the Micro possesses an assembler that turns it into a potential 6502 development system in its own right! It also possesses an operating system that is designed to mesh with assembly language programming in an extraordinarily simple way. One of the aims of this book is to show you how to exploit these features to the full.

The book contains more than 75 listings of programs, many of which will be found to be useful utilities in their own right, quite apart from their 
value in teaching you assembly language. In particular, it contains a full machine code monitor, a suite of machine code sorting programs which you can use on BASIC variables, a high-resolution screen copy to the Epson printer and a program compactor. There is a companion cassette available with the book if you do not feel you want to type in the programs yourself. The cassette also contains two useful extra utility programs. One is a machine code program which will find the locations of any segment of code in a BASIC program (equivalent to the FIND command found in some utility packages); the other is a machine code program which will replace any segment of code in a BASIC program by any other segment; so, for example, you can change any variable's name in the whole program in an instant.

The book is completely self-contained: full information on the $65(02$ instruction set is provided throughout and summarised in an appendix. Other appendixes cover floating-point and the user port.

May 1982

Ian Birnbaum Needingworth 


\section{Preface to the Second Edition}

For this new edition I have incorporated all the extra features of OS 1.2 and of BASIC version 2. In particular, much of chapter 9 on interrupts has been rewritten to take advantage of the event-handling facilities of OS 1.2: and throughout the book, all the powerful OS 1.2 calls have been used where relevant. The useful pseudo-instructions of BASIC 2 have been used where they are appropriate, but equivalent methods for BASIC 1 are also included.

The book has been completely reset and any errors in the first edition corrected.

February 1984

Ian Birnbaum

Kingston-upon-Hull 